\title{
THE PROFILE OF STUDENT'S LOCOMOTOR SKILLS LEVEL IN ELEMENTARY SCHOOL
}

\author{
Risky Syahputra ${ }^{1}$, Syahrial Bakhtiar ${ }^{2}$, Ibnu Andli Marta ${ }^{3}$, Lucy Pratama \\ Putri $^{4}$ \\ Fakultas Ilmu Keolahragaan Universitas Negeri Padang ${ }^{123}$ \\ riskys@fik.unp.ac.id, ibnuandlimarta@fik.unp.ac.id, lucy.pratama@fik.unp.ac.id
}

\begin{abstract}
Based on the observations, the problem of the study is the low level of fundamental motor skills development of children, especially locomotor abilities. The population of this study were all students in Kota Pariaman, the random sampling technique was 67 children. The instrument used to obtain data regarding the level of locomotor development of students was the TGMD-2 instrument subtest, namely: run, hop, jump, gallop and skip. Based on the results, it can be seen that: (1) the students 'ability to run on average is at level 3, (2) the students' hop ability is on average at level 3, (3) the jump ability of the students is on average at level 2, (4) the students 'Gallop Ability on average is at level 2, (5) The students' Skip Ability is on average at level 2.
\end{abstract}

Keywords: : Locomotor skills Level, Elementary School, Student's

\author{
Accepted: 26th of March 2021 \\ Correspondence author: Risky Syahputra, Padang State University, West Sumatera, Indonesia. E-Mail: \\ riskys@fik.unp.ac.id \\ DOI: $h t t p: / / d x$. doi.org/10.31851/hon.v4i2.5378 do
}

\section{c) (i) (2)}

Halaman Olahraga Nusantara Journal licensed under a Creative Commons Attribution-ShareAlike 4.0 International License.

\section{INTRODUCTION}

Recent studies and researches explain that Fundamental Motor Skills (FMS) are an important element that must be mastered by every child from early childhood to elementary school. Data regarding FMS for early childhood and elementary schools in Indonesia is still very limited and understanding of this is also very low (Bakhtiar, 2014). As lecturers and researchers, the author and team conducted a survey on fundamental motor skills knowledge of Primary School Physical Education teachers in several cities and districts in West Sumatra, which shown that teacher knowledge is very low. The primary school level, the FMS of children should be developed so that they acquire more refined motor skills.

Republic of Indonesia Government Regulation number 28 of 1990 CHAPTER II Article 3 explains that basic education aims to provide students with basic abilities to develop their lives as individuals, members of society, citizens and members of the human race and prepare students for secondary education. Understandable This Government Regulation emphasizes teachers to carry out 
education so that children can have the knowledge and skills that become the basis for continuing life to further education.

To be able to realize this government program, it is not only focused on students, but teachers must also have good knowledge and skills in implementing fundamental motor skills. However, teachers' knowledge and abilities are still very low (Goodway et al, 2014). It can be understood that in realizing motion learning for elementary school students, professional teacher skills are needed in teaching.

FMS are seen as the initial foundation for the development and growth of children's fundamental motor skills and will be needed in the future to do sports and other physical activities (Goodway, JD, Ozmun, JC, \& Gallahue, D.L, 2019). If students who have good fundamental motor skills tend to have self-confidence and peer recognition in physical and social activities. Therefore it is very important for teachers to know the level of FMS of students so that in the future learning programs can be designed so that children's FMS can be improved according to their age.

Australia, UK, United States, Belgium, Scotland, South America and Asia in the last decade have conducted research related to FMS. It turns out that these FMS affect many aspects of their children's lives, namely the development of cognitive abilities (Bakhtiar, 2014). It can be understood that mastering FMS properly will provide good benefits for students' cognitive development. Cognitive caused by changes in the physiology of the human body. For example, increased levels of brain-derived neurotrophic factor (BDNF) can facilitate learning and maintain cognitive function by increasing synaptic plasticity and functioning as a neuroprotective agent, leading to increased neuroelectric activity and increased brain circulation (Hillman, C., Erickson, 2008) .

In addition to the cognitive aspects, other aspects that can be developed if students have good FMS are the social aspects of students. Bakhtiar, (2019) explained that mastering these FMS not only affects the psychomotor aspects, but also on the cognitive and associative aspects. The good FMS of students also contribute well to the quality and quantity of motion they do. Basic motion consists of locomotor, non-locomotor and manipulative (control object) motion.

FMS consist of locomotor (running, galloping, hopping, leaping, horizontal jump, and, sliding) and manipulative abilities (striking, stationary dribbling, catching, kicking, overhand throw, and, underhand roll) (Ulrich, 2000). Based on this explanation, there are two basic types of motion that students need to master well, namely locomotors and control / manipulative objects.

Locomotor skills emphasizes gross motor skills that require coordination movements that vary as a child's movement one direction or another. Locomotor skills involve body movement and include skills such as running, skipping and jumping (Ajmol Ali, 2017). The locomotor skills is a fundamental aspect of child development to move from point A to point B (James, 2016). It can be interpreted that locomotor skills is the movement of a child's body from one place to another according to the desired destination.

Although FMS begin at an early age, several studies show that FMS can still be improved and taught until the child is 10 years old or when students are in 
grade 4 of elementary school, Bakhtiar in Oktarifaldi (2019). It is better if fundamental motor skills should be done for both children, adolescents and adults as the main process that will affect physical abilities, Stodden et al (2008). Basically, the locomotor abilities possessed by a student are in accordance with the level of development they should have. However, based on studies and research conducted it is still far from good category, many students have locomotor skills far below their age level. Therefore, the authors will describe the findings in the field which can later become a reference for teachers and policy makers in improving the quality and quantity of movement in education in Indonesia.

\section{Level of Locomotor Skills}

Motor skills are divided into two forms, namely locomotors and control objects. Locomotor skills involve body movement and include skills such as running, skipping and jumping (Ajmol Ali, 2017). Basically, locomotor skills is the ability a child has to be able to move from one point to another according to the level of development they should have.

Locomotor skills emphasizes gross motor skills that require coordination movements that vary as a child's movement one direction or another. Experiences of locomotor activity conducted pasa the past will influence controls the balance owned by children, such as pedestrians who have a better response to stimulation received when doing outdoor activities(MarkoNardini, Dorothy Cowie, (2012).

To know To what extent are the basic locomotor motor skills of students, of course Physical Education teachers including classroom teachers must know and understand the level of FMS. If you understand the level of FMS properly, of course it will be easy to recognize the characteristics of each student to be given improvements and compilation of programs A physical education teacher at elementary school must be able to implement a program that is in accordance with the child's level of movement ability. For the level of locomotor motor skills, it is necessary to know the step of motion and the age of the student as well as the norms that say the delay in movement. The following is a description of the locomotor level that must be used. $\mathrm{s}$ mastered by every teacher in elementary school:

1. Run development level (Run)

a. Level 1, Running with high guard, where (1) arms raised to shoulder level or more, (2) contact feet flat with the floor, (3) short and wide strides steps along with shoulder width.

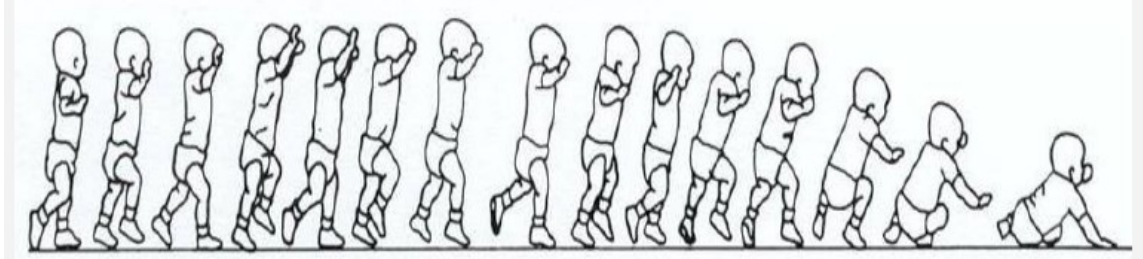

b. Level 2, Running with intermediate guard, where (1) arms are raised to waist level, (2) upper body is kept upright, (3) legs are almost straight 


\section{OLAAAN $\overline{\text { HRAGA }}$}

Jendral A. Yani Street Lorong Gotong Royong 9/10 U1

email jurnal: jurnalhon@univpgri-palembang.ac.id itus web: hup:/lwwwivivpgi-palembangacid

\section{Accredited \\ SINTA 3}
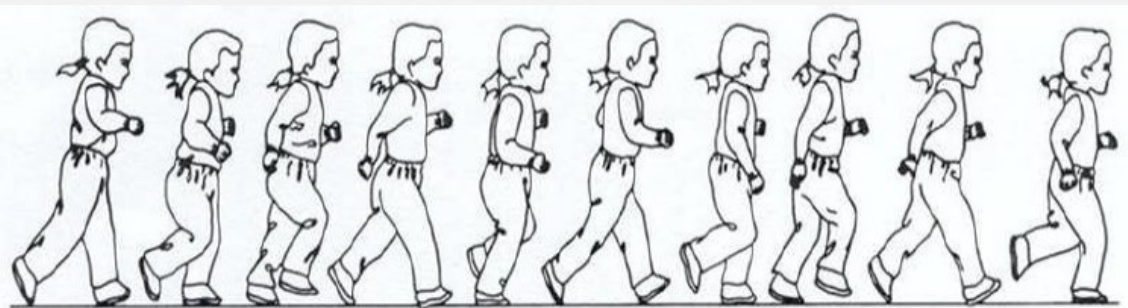

c. Level 3, Run with the "toe" position of the arms extended downwards, where ( 1) arms raised to waist level, (2) arm movement against leg, (3) extended elbow slightly, (4) foot contact starting from heel to fingertip

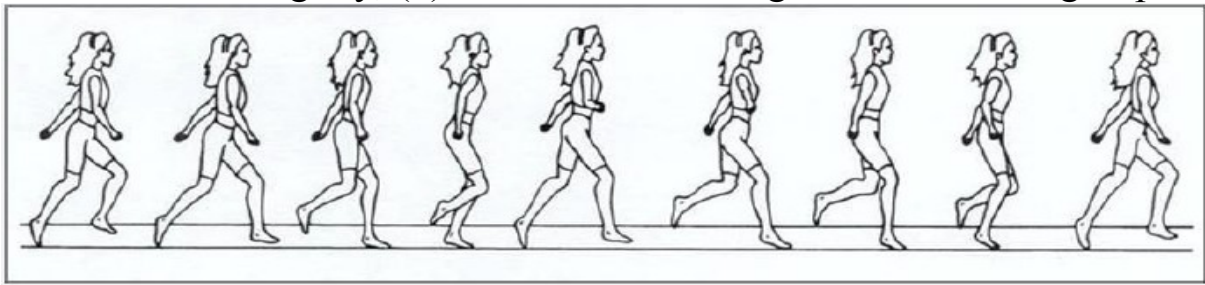

d. Level 4, Running with arm swing, where (1) leg contact starting from the heel - the toes (foot contact starts from the toes - the heel as when running a short distance), (2) the movement of the arm opposite the leg movement, (3) the heel is released high behind the elbow to form close to 90 degrees, (4)

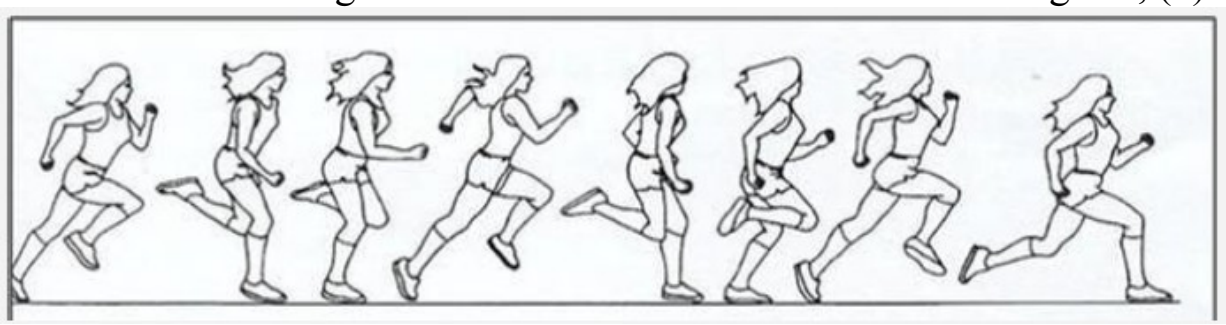

2. Level development of one leg jump (Hop)

a. Level 1, free leg in front of the support leg, where (1) free leg in front of the supporting leg where the thigh is parallel to the floor, (2) the body stands upright, (3) the hands are raised at shoulder level.

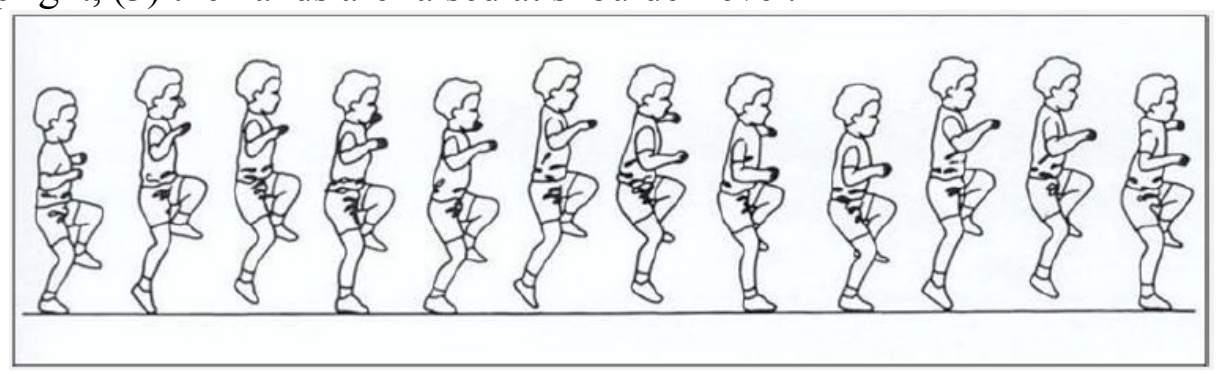

b. Level 2, free leg next to the support leg, where (1) the free knee is bent at the front and the free leg is beside the supporting leg, (2) the body is slightly leaned forward, (3) the arms move in rhythm. 
c. Level 3, the free leg is behind the support leg, where (1) the thigh of the free leg is parallel to the support leg with the knee bent, so that the free leg is behind the supporting leg, (2) the body is more leaned forward, (3) both hands swing to front simultaneously.

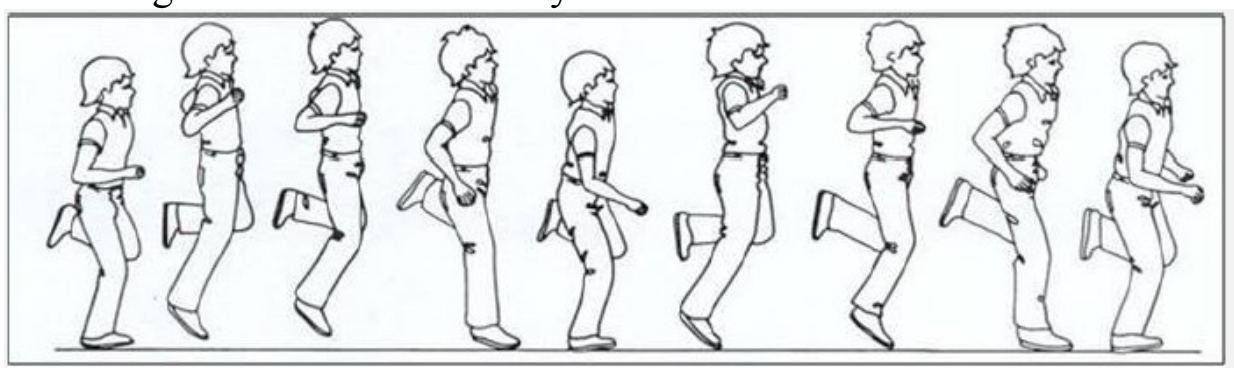

d. Level 4, the free leg is swung beside the support leg, where (1) the free leg is bent and the knee is swinging forward and backward, (2) the body is leaning forward, (3) the arm is swung against the swing of the free leg.

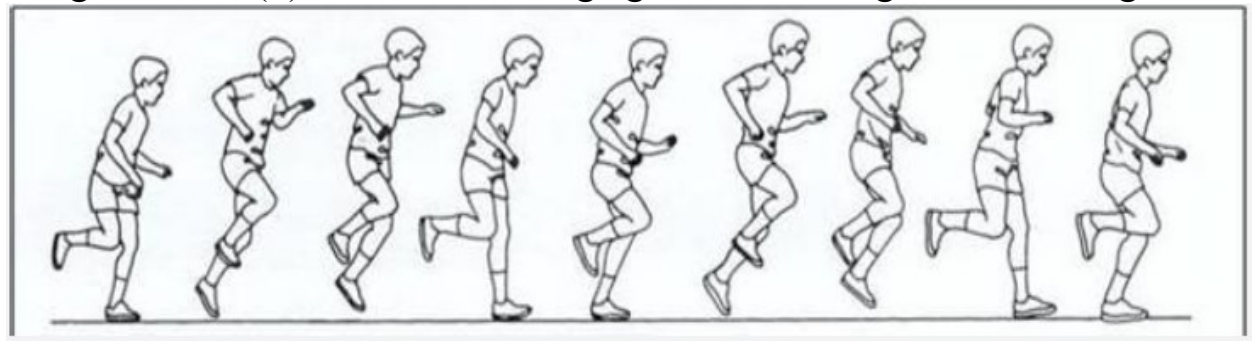

3. Level of development of long jump (Horizontal Jump)

a. Level 1, short jump and the arm functions as a brake, where (1) the arm acts as a "brake" where the arm swings forward during takeoff, then is swung back towards the body when landing, (2) the vertical movement of the body components is still large, (3) the legs are not stretched.

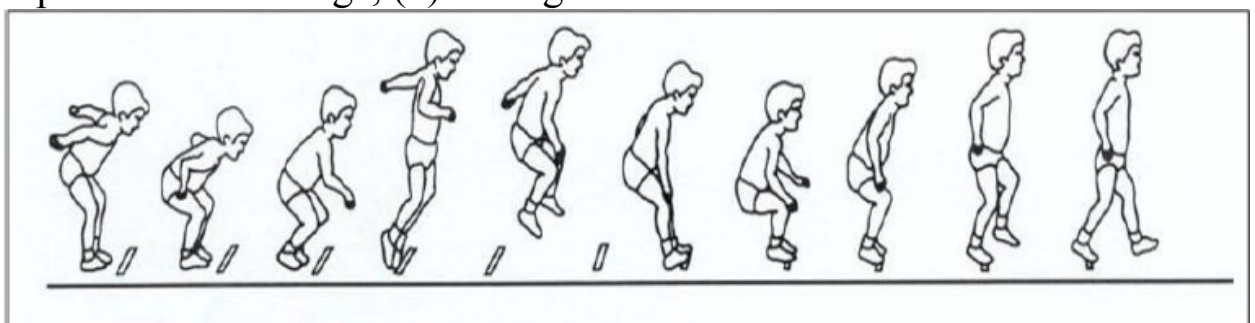




\section{OLA HRAGA}

b. Level 2, the jump is short and the arms are like wings, where (1) the arms act like wings at the sides of the body, (2) the vertical movement of the body components is still large, (3) the legs begin to stretch out straight.

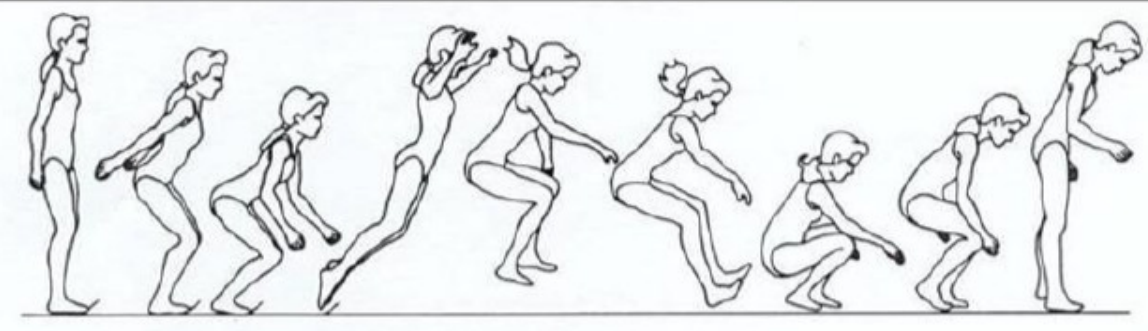

c. Level 3, the jump starts long with the arms swinging towards the front, where (1) the arm moves forward with the elbow in front of the chest when jumping, (2) the hand swings up to head level, (3) the angle of the jump is still above 45 degrees, (4) the legs are often stretched straight.

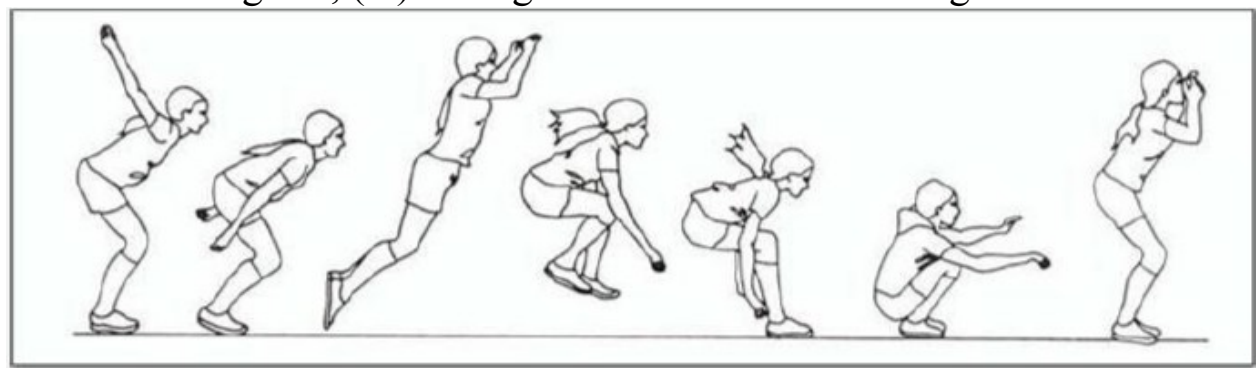

d. Level 4, a long jump with the body stretched perfectly straight, where (1) the arms and legs are actually stretched straight when jumping, (2) the jump is almost at a 45 degree angle, (3) the thighs are parallel to the floor surface when the feet touch the floor when landing .

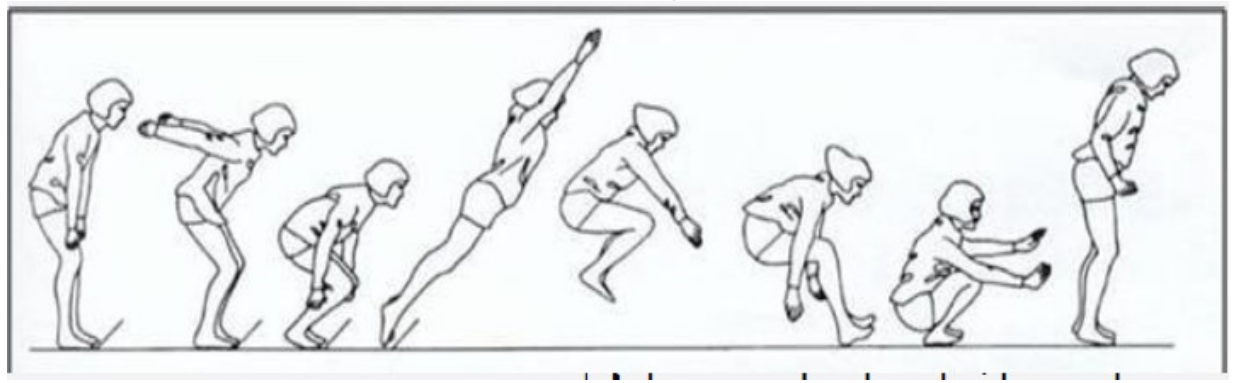

4. The development level of the horse stride (Gallop)

a. Level 1, horse steps resemble irregular running, where (1) resembles running where the rhythm is irregular, (2) the hind legs cross the front legs when floating in the air, (3) the hind legs keep crossing the front legs when landing. 


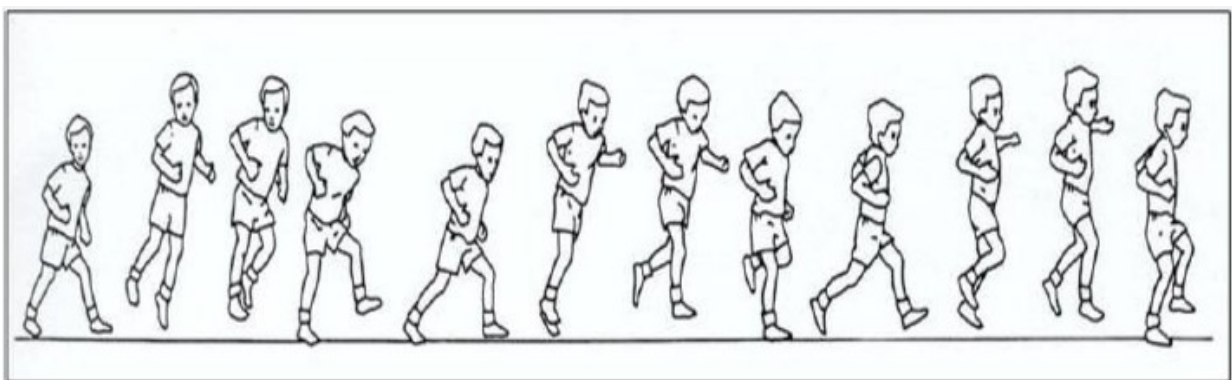

b. Level 2, horse steps with stiff hind limbs, where (1) slow to moderate tempo, broken rhythm, (2) hind legs stiff and dragged, (3) hips often point to the side, (4) vertical movement of body components is still big.

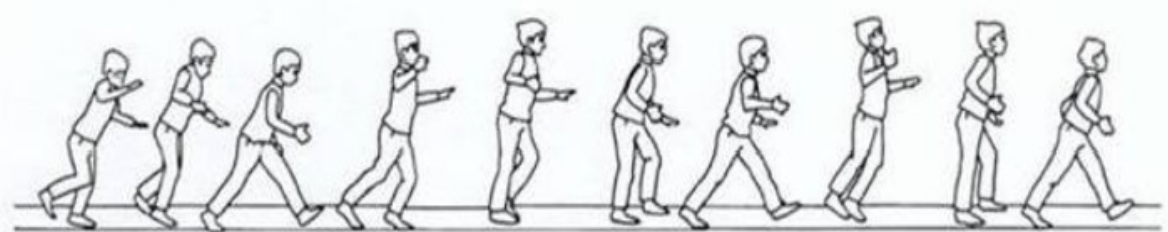

c. Level 3, horse steps with a smooth rhythm, where (1) horse steps with a smooth rhythm, regular rhythm with moderate tempo, (2) feet remain close to the floor, (3) hips point forward.

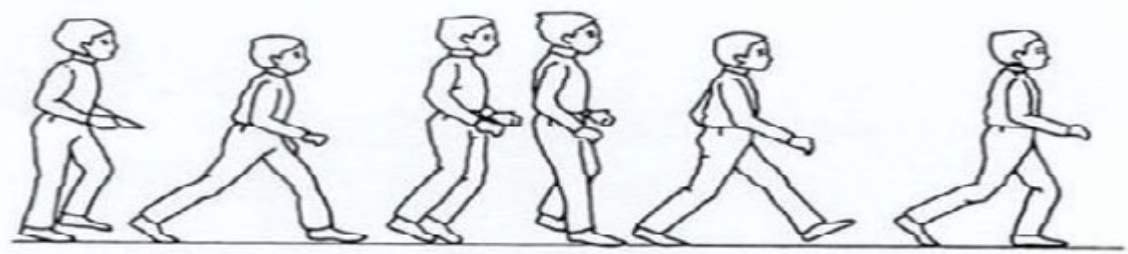

5. The development level of happy running (Skip)

a. Level 1, happy running with imperfect steps, where (1) the step pattern is not perfect or the rhythm is irregular, (2) slow and careful movements, (3) ineffective arm movements.

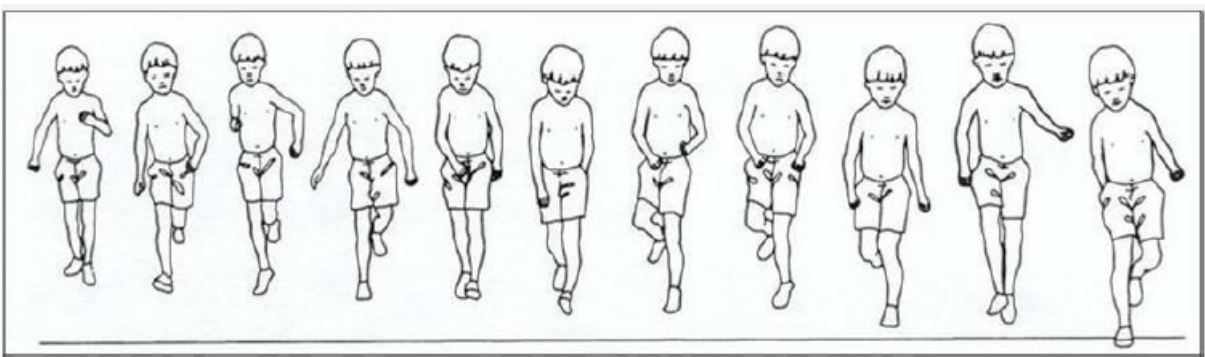


b. Level 2, running is happy with high arm and leg movements, where (1) jumping pattern with a regular rhythm, (2) swinging arms high and helping to lift the body, (3) vertical movement of large body components.

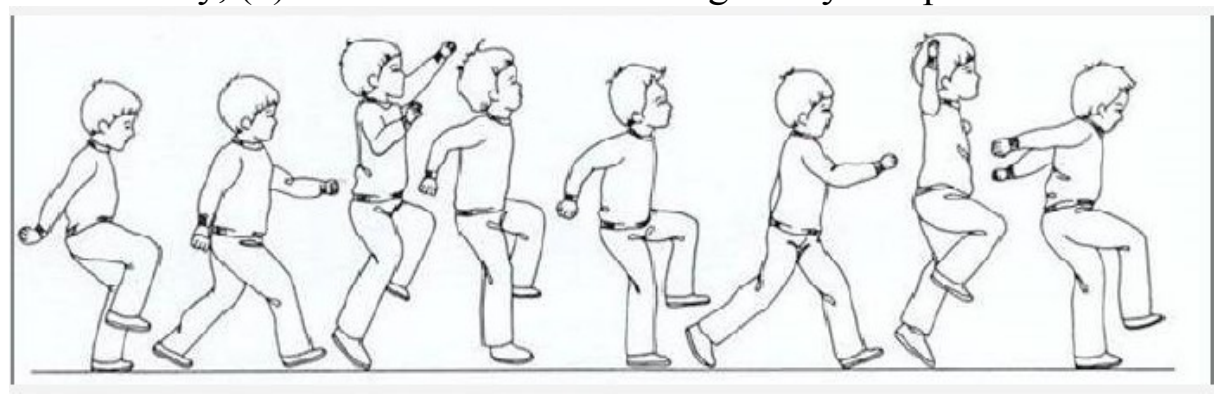

c. Level 3, happy running with a regular rhythm, where (1) reduced arm swing / arm under the shoulder, (2) movement with a regular and relaxed rhythm, (3) the support leg is close to the floor surface when jumping one leg.

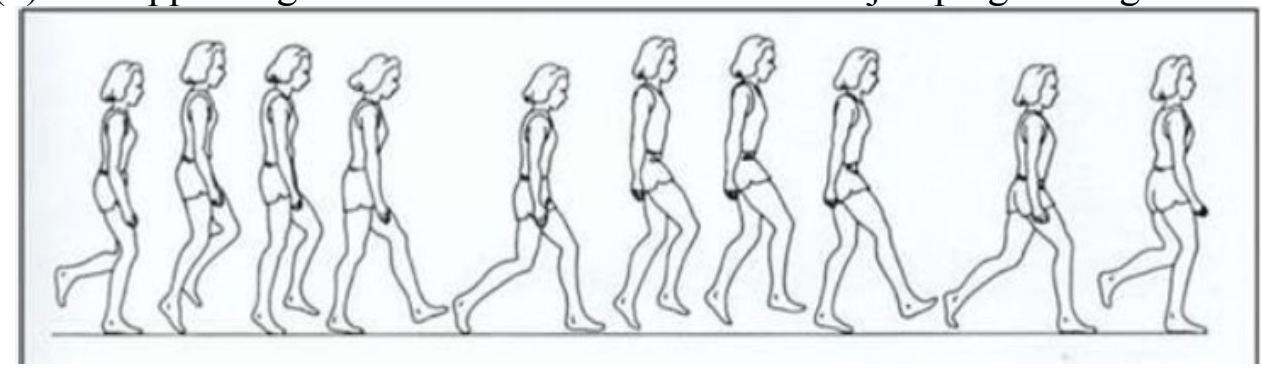

\section{METHOD}

This research is using descriptive quantitative research. Descriptive research is a research method that seeks to describe the object or subject under study in accordance with the facts obtained (Arikunto, 2016). This study used a sample of 67 students at SD Negeri 29 Kota Pariaman consisting of 28 male students and 39 female students aged 7 to 8 years. Data on levels of motor skills locomotor of the instrument Test of Gross Motor Development Second Edition (TGMD-2), including dalah: run(run),jump satuu foot(hop),diving without a prefix(horizontalrun), step horses(gallop)and happy step step jump (skip). Data obtained by recording every ability performed by each research sample. Then the data is coded by paying attention to the level of FMS in each of the abilities being tested (Bakhtiar, 2015).

The researcher uses descriptive statistical analysis with the percentage formula in order to get a percentage of the data that has been collected, as follows:

Information:

$$
p=\frac{f}{n} \times 100 \%
$$

$\begin{array}{ll}\mathrm{P} & : \text { Percentage } \\ \mathrm{f} & : \text { Frequency } \\ \mathrm{n} & : \text { Many Sample }\end{array}$




\section{OLATRAGA}

Jendral A. Yani Street Lorong Gotong Royong 9/10 U1

JIR.AL MIIIhiOLIJRANTARA email jurnal: jurnalhon@univpgri-palembang.ac.id

\section{RESULTS AND DISCUSSIONS}

1. Running Ability

This running ability has 4 levels that must be mastered by each children in early childhood. As a child grows older and is accompanied by the provision of intervention, the level of ability in running that is owned by the child should be higher as well. The following describes the level of running abilities possessed by students at SD Negeri 29 Kota Pariaman aged 7 to 8 years.

Table 1. Run Ability Level

\begin{tabular}{cccc}
\hline No & Level & $\begin{array}{c}\text { Absolute } \\
\text { Frequency }\end{array}$ & $\begin{array}{c}\text { Relative } \\
\text { Frequency }\end{array}$ \\
\hline $\mathbf{1}$ & 1 & 0 & $0 \%$ \\
$\mathbf{2}$ & 2 & 8 & $12 \%$ \\
$\mathbf{3}$ & 3 & 38 & $57 \%$ \\
$\mathbf{4}$ & 4 & 21 & $31 \%$ \\
& Total & $\mathbf{6 7}$ & $\mathbf{1 0 0 \%}$ \\
\hline
\end{tabular}

Based on the table above, from 67 students in SD Negeri 29 Kota Pariaman that has been tested for their running ability, not a single student is at level 1. At level 2 there are 8 students (12\%). At level 3 there are 38 students $(57 \%)$ while at level 4 there are 21 people $(31 \%)$. In order to be clearer about the level of running ability possessed by students at SD Negeri 29 Kota Pariaman aged 7 to 8 years based on gender, the researchers describe it in the form of a table below.

Table 2. Level Capabilities of Run by Sex

Male

Female

\begin{tabular}{cccccc}
\hline Level & $\begin{array}{c}\text { Absolute } \\
\text { Frequency }\end{array}$ & $\begin{array}{c}\text { Relative } \\
\text { Frequency }\end{array}$ & Level & $\begin{array}{c}\text { Absolute } \\
\text { Frequency }\end{array}$ & $\begin{array}{c}\text { Relative } \\
\text { Frequency }\end{array}$ \\
\hline 1 & 0 & $0 \%$ & 1 & 0 & $0 \%$ \\
2 & 0 & $0 \%$ & 2 & 8 & $21 \%$ \\
3 & 19 & $68 \%$ & 3 & 19 & $49 \%$ \\
4 & 9 & $32 \%$ & 4 & 12 & $31 \%$ \\
\hline Total & $\mathbf{2 8}$ & $\mathbf{1 0 0 \%}$ & & $\mathbf{3 9}$ & $\mathbf{1 0 0 \%}$ \\
\hline
\end{tabular}


2. Ability to Jump One Leg $(H o p)$

One leg jump is an asymmetric ability that requires a student to jump and land using the same leg. To perform this ability requires leg strength and dynamic balance because when doing this ability only relies on one leg. In many sports, in order to maximize basic technical skills, a person is required to master the ability to jump one leg (hops). For example, doing lay ups and triple jumps in basketball, balestra in fencing and many more (Australia, 2013). Next, the researchers describe the data that researchers have obtained in the field regarding the ability ofone leg (hophopstudents to) at SD Negeri 29 Kota Pariaman.

Table 3. Ability Level of One leg jump (hop)

\begin{tabular}{cccc}
\hline No & Level & $\begin{array}{c}\text { Absolute } \\
\text { Frequency }\end{array}$ & $\begin{array}{c}\text { Relative } \\
\text { Frequency }\end{array}$ \\
\hline $\mathbf{1}$ & 1 & 0 & $0 \%$ \\
$\mathbf{2}$ & 2 & 10 & $15 \%$ \\
$\mathbf{3}$ & 3 & 32 & $48 \%$ \\
$\mathbf{4}$ & 4 & 25 & $37 \%$ \\
& Total & $\mathbf{6 7}$ & $\mathbf{1 0 0 \%}$ \\
\hline
\end{tabular}

Based on the table above, out of 67 participants students in SD Negeri 29 Kota Pariaman who have been tested for the ability to jump one leg, there is not a single student who is at level 1. At level 2 there are 10 students (15\%). At level 3 there are 32 students (48\%) while at level 4 there are 25 students (37\%). In order to be clearer about the level of the ability to jump one leg that is owned by students at SD Negeri 29 Kota Pariaman aged 7 to 8 years based on gender, the researchers describe it in the form of the table below.

Table 4. Ability level of jump one leg (hop) by sex Male Female

\begin{tabular}{cccccc}
\hline Level & $\begin{array}{c}\text { Absolute } \\
\text { Frequency }\end{array}$ & $\begin{array}{c}\text { Relative } \\
\text { Frequency }\end{array}$ & Level & $\begin{array}{c}\text { Absolute } \\
\text { Frequency }\end{array}$ & $\begin{array}{c}\text { Relative } \\
\text { Frequency }\end{array}$ \\
\hline 1 & 3 & $11 \%$ & 1 & 8 & $21 \%$ \\
2 & 11 & $39 \%$ & 2 & 18 & $46 \%$ \\
3 & 6 & $21 \%$ & 3 & 7 & $18 \%$ \\
4 & 8 & $29 \%$ & 4 & 6 & $15 \%$ \\
\hline Total & $\mathbf{2 8}$ & $\mathbf{1 0 0} \%$ & & $\mathbf{3 9}$ & $\mathbf{1 0 0 \%}$ \\
\hline
\end{tabular}

3. The ability Skip No Prefix(HorizontalJump)

147 | Halaman Olahraga Nusantara

copyright@Risky Syahputra 
Jump is a fundamental movement that occurs when the body jumps into the air with the force produced pedestal legs and the body landed with both feet (Pasand, 2016). The ability to jump without prefix also has a level that must be achieved by students. Although actually this ability must be mastered by students at an early age. However, in fact there are still many students aged 7 to 8 years who are still unable to master this ability to its full potential. The following is an explanation of the results of research that researchers have conducted some time ago at SD Negeri 29 Kota Pariaman.

Table 5. Level Capabilities of Skip Away(HorizontalJump)

\begin{tabular}{cccc}
\hline No & Level & $\begin{array}{c}\text { Absolute } \\
\text { Frequency }\end{array}$ & $\begin{array}{c}\text { Relative } \\
\text { Frequency }\end{array}$ \\
\hline $\mathbf{1}$ & 1 & 19 & $28 \%$ \\
$\mathbf{2}$ & 2 & 44 & $66 \%$ \\
$\mathbf{3}$ & 3 & 4 & $6 \%$ \\
$\mathbf{4}$ & 4 & 0 & $0 \%$ \\
\hline \multicolumn{2}{c}{ Total } & $\mathbf{6 7}$ & $\mathbf{1 0 0 \%}$ \\
\hline
\end{tabular}

Based on the above table, from 67 participants There were not as many as 19 students (28\%) who were at level 1. At level 2 there were 44 students $(66 \%)$. At level 3 there are 4 students $(6 \%)$ while at level 4 there are no students. In order to be clearer about the level of ability to jump without prefix which is owned by students at SD Negeri 29 Kota Pariaman aged 7 to 8 years based on gender, the researchers describe it in the form of the table below.

Table 6. Level Capabilities of Skip Away(HorizontalJump) by Sex

\begin{tabular}{cccccc} 
& \multicolumn{2}{c}{ Male } & \multicolumn{2}{c}{ Female } \\
\hline Level & $\begin{array}{c}\text { FrequencyAbs } \\
\text { olute }\end{array}$ & $\begin{array}{c}\text { RelativeFrequ } \\
\text { ency }\end{array}$ & Level & $\begin{array}{c}\text { FrequencyAbso } \\
\text { lute }\end{array}$ & $\begin{array}{c}\text { Relative } \\
\text { Frequency }\end{array}$ \\
\hline 1 & 4 & $14 \%$ & 1 & 15 & $38 \%$ \\
2 & 20 & $71 \%$ & 2 & 24 & $62 \%$ \\
3 & 4 & $14 \%$ & 3 & 0 & $0 \%$ \\
4 & 0 & $0 \%$ & 4 & 0 & $0 \%$ \\
\hline Total & $\mathbf{2 8}$ & $\mathbf{1 0 0 \%}$ & & $\mathbf{3 9}$ & $\mathbf{1 0 0 \%}$ \\
\hline
\end{tabular}

4. Capability Step Horses(Gallop) 
Gallop is continuous locomotor movement with a forward direction in which the movement is a combination of running and leaping. Gallop is an asymmetrical gait because it involves a step to the dominant foot that is in front and then a jump to the other leg, the dominant foot will always be in front of the non-dominant foot. This ability is widely used in various games, dances and activities during childhood (Australia, 2013).

Table 7. The Ability Level of Horse Steps (Gallop)

\begin{tabular}{cccc}
\hline No & Level & $\begin{array}{c}\text { Absolute } \\
\text { Frequency }\end{array}$ & $\begin{array}{c}\text { Relative } \\
\text { Frequency }\end{array}$ \\
\hline $\mathbf{1}$ & 1 & 22 & $33 \%$ \\
$\mathbf{2}$ & 2 & 44 & $66 \%$ \\
$\mathbf{3}$ & 3 & 1 & $1 \%$ \\
\hline \multicolumn{2}{c}{ Total } & $\mathbf{6 7}$ & $\mathbf{1 0 0 \%}$ \\
\hline
\end{tabular}

Based on the table above, out of 67 students in SD Negeri 29 Cities There were not as many as 22 students $(33 \%)$ who were at level 1 . At level 2 there were 44 students $(66 \%)$. At level 3 there are 1 students $(1 \%)$. In order to be clearer about the level of horse-stepping skills possessed by students at SD Negeri 29 Kota Pariaman aged 7 to 8 years based on gender, the researchers describe it in the form of a table below.

Table 8. Level Capability of Step Horses(Gallop) by Sex Male Female

\begin{tabular}{cccccc}
\hline Level & $\begin{array}{c}\text { Absolute } \\
\text { Frequency }\end{array}$ & $\begin{array}{c}\text { Relative } \\
\text { Frequency }\end{array}$ & Level & $\begin{array}{c}\text { Absolute } \\
\text { Frequency }\end{array}$ & $\begin{array}{c}\text { Relative } \\
\text { Frequency }\end{array}$ \\
\hline 1 & 7 & $25 \%$ & 1 & 15 & $38 \%$ \\
2 & 21 & $75 \%$ & 2 & 23 & $59 \%$ \\
3 & 0 & $0 \%$ & 3 & 1 & $3 \%$ \\
\hline Total & $\mathbf{2 8}$ & $\mathbf{1 0 0 \%}$ & & $\mathbf{3 9}$ & $\mathbf{1 0 0 \%}$ \\
\hline
\end{tabular}




\section{Capability Step of Happy-Go Step (skip)}

Table 9. Level capability Step Glad Step-Jump(Skip)

\begin{tabular}{cccc}
\hline No & Level & $\begin{array}{c}\text { Absolute } \\
\text { Frequency }\end{array}$ & $\begin{array}{c}\text { Relative } \\
\text { Frequency }\end{array}$ \\
\hline $\mathbf{1}$ & 1 & 13 & $19 \%$ \\
$\mathbf{2}$ & 2 & 29 & $43 \%$ \\
$\mathbf{3}$ & 3 & 25 & $37 \%$ \\
\hline \multicolumn{2}{c}{ Total } & $\mathbf{6 7}$ & $\mathbf{1 0 0 \%}$
\end{tabular}

Based on the table above, of the 67 students in SD Negeri 29 Kota Pariaman who had been tested for their ability to jump without starting, there were not as many as 13 students (19\%) who were at level 1 . At level 2 there were as many as 29 students (43\%). At level 3 there are 25 students (37\%). In order to be clearer about the level of ability of the students in SD Negeri 29 Kota Pariaman aged 7 to 8 years based on gender, the researchers describe it in the form of a table below.

Table 10. Ability Level Glad Step Step-Jump (Skip) By Gender

Male Female

\begin{tabular}{cccccc}
\hline Level & $\begin{array}{c}\text { Absolute } \\
\text { Frequency }\end{array}$ & $\begin{array}{c}\text { Relative } \\
\text { Frequency }\end{array}$ & Level & $\begin{array}{c}\text { Absolute } \\
\text { Frequency }\end{array}$ & $\begin{array}{c}\text { Relative } \\
\text { Frequency }\end{array}$ \\
\hline 1 & 8 & $29 \%$ & 1 & 5 & $13 \%$ \\
2 & 10 & $36 \%$ & 2 & 19 & $49 \%$ \\
3 & 10 & $36 \%$ & 3 & 15 & $38 \%$ \\
\hline Total & $\mathbf{2 8}$ & $\mathbf{1 0 0 \%}$ & & $\mathbf{3 9}$ & $\mathbf{1 0 0 \%}$ \\
\hline
\end{tabular}

\section{DISCUSSION}

Running is one of the most FMS required in everyday activities (for example, a learner will run because he or she is late for school). Running is also a basic skill required in many physical activities, games and sports (e.g. athletics, soccer, basketball). Proficiency and mastery of good running techniques for various situations will allow children to move confidently (Liang, 2013). Ideally, this ability to run will increase with age, assisted by the provision of interventions. Based on the explanation from Goodway et al (2019), there are four levels of running ability that every child must master at an early age according to the age 
they are experiencing. So that by the time they reach school age, they have mastered the ability to run at the maximum level.

Based on the findings, the researchers saw the maximum running ability level, namely level 4, which should have been mastered by students at the age of 5.5 years, could not even be mastered by all students who were recorded as the sample. Only 21 students or $31 \%$ only reached the maximum level. This finding is of course a concern for all people because the ability to run is not only synergized with children's activeness in physical activities, but also closely related to physical fitness that must be achieved by students to get satisfactory learning outcomes as students.

This low level of running ability is because during early childhood children are not given basic exercises regarding FMS, especially running which causes students to be weak in performing this ability. This happens because parents and even the surrounding environment do not know the importance of teaching children running skills to support physical and motor development in children. In addition, during the school years, many teachers did not pay attention to this due to a lack of insight and knowledge regarding this matter.

\section{Jump One Leg(Hop)}

\section{Skip No Prefix (Horizontal Jump)}

The bolt can be done in several ways. Keogh and Sugden (Pasand, 2016) suggest that the best way for a child to jump forward is to use a two-foot pedestal. In doing jumps without prefix, students to push the body up the front as strong as possible.

\section{Step Horses(Gallop)}

Galloping is slid forward movement: the front foot stepped forward with a little spring followed by removal of the body weight to the back foot. When the hind leg takes the weight of the body, the front leg repeats the forward stepping motion. The same guide foot is always in front during a race. Galloping is commonly used in dances (e.g., children's, folk, and line dances). Children enjoy the fun, light movements that give them the feeling of riding a horse. This ability 
consists of 3 levels, namely levels 1,2 and 3, where each student must have mastered this ability at the age of 6.5 years.

However, in fact, after the researcher conducted a study at SD Negeri 29 Kota Pariaman, the researcher found that there were still many students aged 7 to 8 years at this school who had not yet reached the maximum level of mastery of the ability to move the horse (gallop). In fact, of the 67 students who the researchers sampled in this study only 1 student was able to masterability gallop thisto the maximum level, namely level 3 . These findings indicate that students in this school were not given enough training by their parents and teachers. during the early stages of their growth and development. So that these students are not able to reach the maximum level that they should have achieved at their current age perfectly.

\section{Skip the Happy Steps (Skip)}

Parents and even teachers from early childhood to elementary school levels still think that mastering FMS in children is not an important thing to be afraid of because as we get older these skills will develop by themselves. In addition, teachers are also not given knowledge and insights about FMS and the importance of teaching fundamental motor skills to students (Bakhtiar and Famelia in Oktarifaldi et al., 2019) (Famelia et al in Bakhtiar et al., 2019). The reality in the field is inversely proportional to what parents and teachers understand so far, that in fact these FMS will only develop if they are given adequate training and intervention (Bolger et al in Putri et al., 2020).

\section{CONCLUSIONS}

Based on the research results, after conducting statistical analysis and hypothesis testing, it can be concluded in general that group guidance services using theapproach discovery learning can reduce student academic procrastination in working on theses. Specifically, the findings of this study are as follows.

1. There is a significant difference in students' academic procrastination before and after being given group guidance services using theapproach discovery learning. 
2. Group guidance services using theapproach are discovery learning considered effective in reducing student academic procrastination in working on their thesis.

3. Student academic procrastination before being given group guidance services using theapproach discovery learning is in the high category and after being given group guidance services the level of student academic procrastination has decreased.

\section{REFERENCES}

Ali, A., Pigou, D., Clarke, L., \& McLachlan, C. (2017). Literature review on motor skill and physical activity in preschool children in New Zealand.

Arikunto, S. (2016). Prosedur Penelitian Suatu Pendekatan Praktik. Jakarta: Rineka Cipta.

Australia, D. of E. W. (2013). Fundamental movement skills: Book 2 - The tools for learning, teaching and assessment.

Bakhtiar, S. (2014). Fundamental motor skill among 6-year-old children in Padang, West Sumatera, Indonesia. Asian Social Science, 10(5), 155-158.

Bakhtiar, S. (2015). Merancang Pembelajaran Gerak Dasar Anak. In UNP Press.

Bakhtiar, S., Johor, Z., Oktarifaldi, \& Putri, L. P. (2019). Implementation of Learning and Fundamental Measurement of Early Childhood Motor Skill for PAUD Teachers Padang Panjang City. Journal Humanities, 1(1), 36-47.

Bakhtiar, Syahrial, Khairuddin Khairuddin, Reki Yelis, Lucy Pratama Putri, and Suci Nanda Sari. "Pengaruh Umpan Balik, Koordinasi terhadap Kemampuan Objek Kontrol Siswa Paud." Sporta Saintika 5, no. 1 (2020): 59-71.

Bakhtiar, S., Putra, E. R., Oktarifaldi, O., \& Putri, L. P. (2019). Pengaruh Koordinasi Mata-Tangan, Body Mass Index dan Gender Terhadap Kemampuan Object Kontrol pada Anak PAUD Kota Pariaman. Jurnal MensSana, 4(2), 165-174.

Goodway, J. D., Ozmun, J. C., \& Gallahue, D. L. (2019). Understanding motor development: Infants, children, adolescents, adults. Jones \& Bartlett Learning.

Gibson, N., Chappell, A., Blackmore, A. M., Morris, S., Williams, G., Bear, N., \& Allison, G. (2018). The effect of a running intervention on running ability 
and participation in children with cerebral palsy: a randomized controlled trial. Disability and Rehabilitation, 40(25), 3041-3049. https://doi.org/10.1080/09638288.2017.1367426

Jacqueline D, G., Famelia, R., \& Bakhtiar, S. (2014). Future directions in physical education \& sport: Developing fundamental motor competence in the early years is paramount to lifelong physical activity. Asian Social Science, 10(5), 44-54.

Hillman, C. H., Erickson, K. I., \& Kramer, A. F. (2008). Be smart, exercise your heart: exercise effects on brain and cognition. Nature reviews neuroscience, $9(1), 58-65$.

Liang, R. S. Y. (2013). Parents' guide for growing active learners Parents' guide for growing active learners. www.ssc.gov.sg

Nardini, M., \& Cowie, D. (2012). The development of multisensory balance, locomotion, orientation, and navigation.

Nomor, P. P. R. I. (28). Tahun 1990 Tentang Pendidikan Dasar, 1990. Adapted from http://simpuh. kemenag. go. id/regulasi/pp_28_90. pdf.

Oktarifaldi, O., Syahputra, R., \& Putri, L. P. (2019). Pengaruh Kelincahan, Koordinasi Dan Keseimbangan Terhadap Kemampuan Lokomotor peserta didik Usia 7 Sampai 10 Tahun. Jurnal MensSana, 4(2), 190. https://doi.org/10.24036/jm.v4i2.117

Pasand, F. (2016). Evaluation of standing long jumping fundamental skill developmental sequence in children. International Journal Of Biology, Pharmacy and Allied Sciences (IJBPAS), February, 4568-4578.

Putri, L. P., Syahputra, R., \& Andli, I. (2020). Kinestetik: Jurnal Imiah Pendidikan Jasmani NUTRITIONAL STATUS EFFECT ON OBJECT CONTROL ABILITY IN CHILDREN AGE 5 TO 6 YEAR. 4(2), 25-32.

Rudd, J. (2016). The efficacy of gymnastics to improve movement skill competence in children (Doctoral dissertation, Victoria University).

Stodden, D. F., Goodway, J. D., Langendorfer, S. J., Roberton, M. A., Rudisill, M. E., Garcia, C., \& Garcia, L. E. (2008). A developmental perspective on the role of motor skill competence in physical activity: An emergent relationship. Quest, 60(2), 290-306. 